\title{
Mechanical and Microstructural Properties of Copper Slag Based Blended Geopolymer Concrete
}

\author{
Vijayasarathy RATHANASALAM*, Jayabalan PERUMALSAMI, \\ Karthikeyan JAYAKUMAR
}

\author{
Department of Civil Engineering, National Institute of Technology, Tiruchirappalli, Tamil Nadu, 620015, India \\ crossref http://dx.doi.org/10.5755/j02.ms.26521
}

Received 05 June 2020; accepted 30 June 2020

\begin{abstract}
This work presents a novel way to examine the characteristics of fly ash, copper slag (CPS) along with the addition of Ultrafine Ground Granulated Blast Furnace Slag (UFGGBFS) based Geopolymer Concrete (GPC) for various molarities (10M, 12M and 14M). In GPC, fly ash was replaced with UFGGBFS (5 \%, $10 \%$ and $15 \%)$ and copper slag was used as fine aggregate. Mechanical Characterization such as split tensile, flexural strength, workability and water absorption were conducted. GPC characterization and microstructural behaviour was studied by examining X-ray diffraction (XRD) and Scanning Electron Microscopy (SEM). From experimental results this study concludes that with a rise in molarity of GPC, along with incorporation of UFGGBFS, improved the performance, densification and strength of GPC.

Keywords: copper slag, fly ash, molarity, geopolymer concrete, ultrafine ground granulated blast furnace slag.
\end{abstract}

\section{INTRODUCTION}

The manufacturing procedure of cement consumes many natural resources, and causes major problems to the society, predominant hazard being the emission of greenhouse gases [1]. A ton of cement production results in an equal amount of $\mathrm{CO}_{2}$ emission [2-6]. Global production of cement per year would rise up to $5 \%$ in the future; and in 2050, it will elevate to 4.38 billion tonnes [7]. In order to reduce $\mathrm{CO}_{2}$ emissions, researchers are working on the application of eco-friendly materials. One of such material is alkali activated geopolymer concrete [8]. Geopolymer concrete acts as an emerging alternative to conventional concrete and holds the potential to convert wastes like fly ash, slags and other waste products into useful by-products [9]. Better geopolymerization occurs while incorporating Ground Granulated Blast Furnace Slag (GGBFS) and fly ash, which resulted in good stability and performance [10]. The durability and mechanical strength characteristics of conventional concrete were found to be less when compared to GPC at elevated temperatures [11, 12]. The strength of GPC mainly depends on the curing condition. At ambient temperature setting time is more; this is due to the gel form nature of sodium silicate; to counteract this issue GPC is cured at $60{ }^{\circ} \mathrm{C}$ for a period of 24 and 48 hours respectively [13]. Usage of heat-cured process is not cost-effective and causes practical problem for in-situ cases; thereby it could not be applied for massive geopolymer concrete applications. Certain studies have shown that an Ordinary Portland Cement (OPC) when combined with low calcium fly ash, accelerates the curing of GPC rather than curing by heat application [14]. Heat curing is best suited for the precast industry. To overcome the practical curing problems, investigation on ambient curing should be done. Growth of the Construction industry requires a huge quantity of sand. Sand mining from river bed and beaches pose a serious environmental threat. Continuous sand mining results in an improper river flow, affecting the native flora, fauna and the aquifers [15]. Manufacturing one ton of copper, results in two to three tons of CPS [16]. Annual production of CPS in India is about 3.5 million tons which are used for eliminating rust and many impurities [17]. These findings have awakened the construction industry. Furthermore the disposal of these slags requires a huge land area, thereby causing land pollution. To counteract these challenges researchers are working on alternative fine aggregate and binder. In this study GPC made of CPS as fine aggregate was examined, GPC showed good strength performance along with CPS [18]. CPS used as fine aggregate in GPC showed an increase in strength than control concrete by 1.35 times, increase in quantity of copper slag increased the compressive strength [19]. Numerous studies have proved that the strength of GPC improved due to short term elevated temperature [20, 21]. Even though a lot of research has been conducted on slag materials, practical application of slag materials and its behavior has always been a grey area. Behavior of GPC made of UFGGBFS and high volume copper slag at ambient curing is unfathomed. In this novel study, geopolymer concrete (10M, 12M and 14M) was made by replacing low calcium fly ash with ultra-fine GGBFS for $0 \%, 5 \%, 10 \%$ and $15 \%$ respectively as a binder and copper slag was used as fine aggregate. Ambient curing was employed in order to check its suitability for the construction industry. Since many researches have studied about compression strength, in this study flexural and split tensile strength properties

\footnotetext{
* Corresponding author. Tel.: +91-9994486655; +91-8870092762.

E-mail address: rvsarathycivil@gmail.com (V. Rathanasalam)
} 
were examined along with workability. To analyse the structure of fly ash and UFGGBFS based GPC for different sodium hydroxide $(\mathrm{NaOH})$ concentration, XRD and SEM analysis were performed. Several researchers have examined about early age strength of GPC [20 - 22], so in this work, experiments were conducted after the age of 7 and 28 days of standard curing.

\section{EXPERIMENTAL INVESTIGATIONS}

\subsection{Materials}

Fly ash (Class F) having specific gravity 2.64 was procured from the Mettur Thermal Power Plant, India, and was utilized as the primary material. XRF analysis of fly ash was performed to study the chemical composition and to satisfy the requirements as per IS 3812: 2003 [23]. The chemical and physical composition of fly ash is tabulated in Table 1. UFGGBFS, a micro-fine low calcium silicate material of size 4 to 6 microns, improves the hardened and fresh property of concrete [24]. The physical properties along with the chemical composition of UFGGBFS are displayed in Table 2. The well-graded coarse aggregate of $12.5 \mathrm{~mm}$ size with a specific gravity of 2.83, confirming to IS 383:2006 Standard [25] were used. Copper slag, a black colored glassy granular particle satisfying IS 2386. Part I:1963 Standard [26], was utilized as a fine aggregate. Table 3 displays the physical properties along with the chemical composition of CPS. To improve the workability of GPC, super plasticizer (based on Naphthalene sulfonate) in liquid form was used as an admixture confirming to IS 9103:1999 Standard [27].

\subsection{Alkaline solution}

The geopolymerization process mainly occurs due to alkaline activators such as sodium hydroxide $(\mathrm{NaOH})$ and sodium silicate $\left(\mathrm{Na}_{2} \mathrm{SiO}_{3}\right)$. A solution of $\mathrm{NaOH}$ was made for $10 \mathrm{M}, 12 \mathrm{M}$ and $14 \mathrm{M}$ by using $98 \%$ purity pellets. Commercially available sodium silicate was then mixed with 2.5 times sodium hydroxide to make GPC.

\subsection{Preparation of geopolymer concrete specimen}

$\mathrm{NaOH}$ solution prepared for $10 \mathrm{M}$ (314 grams of $\mathrm{NaOH} / 1 \mathrm{~L}$ of $\mathrm{NaOH}$ solution), 12M (361 grams of
$\mathrm{NaOH} / 1 \mathrm{~L}$ of $\mathrm{NaOH}$ solution) and 14M (404 grams of $\mathrm{NaOH} / 1 \mathrm{~L}$ of $\mathrm{NaOH}$ Solution) were used as alkaline solution. Preparation of $\mathrm{NaOH}$ was done at room temperature, after 24 hours $\mathrm{Na}_{2} \mathrm{SiO}_{3}$ was mixed to $\mathrm{NaOH}$ solution. $\mathrm{Na}_{2} \mathrm{SiO}_{3} / \mathrm{NaOH}$ ratio was formulated as 2.5. Alkaline liquid to binder ratio was kept as 0.35 . UFGGBFS (0 \%, $5 \%, 10 \%$ and $15 \%$ ) partially replaced with fly ash and CPS as fine aggregate was mixed with an alkaline solution to make GPC. The percentage of UFGGBFS replacement was restricted to $15 \%$, because any percentage of replacement higher than $15 \%$ results in flash set. Specimens contain UFGGBFS (0 \%, $5 \%, 10 \%$ and $15 \%$ ) along with fly ash and copper slag for different $\mathrm{NaOH}$ molarities (10M, $12 \mathrm{M}$ and $14 \mathrm{M}$ ) were cast as per Indian standard code and testing was done after curing of 7 days and 28 days. Curing of geopolymer concrete specimens has been done in two ways. In the first case, where fly ash has been used as the only binder, curing in oven at $60^{\circ} \mathrm{C}$ has been adopted. In the second case, where fly ash has been replaced by $5 \%, 10 \%$ and $15 \%$ UFGGBFS, curing of geopolymer concrete specimens in the laboratory at ambient temperature has been adopted. Prisms of size $10 \mathrm{~cm} \times 10 \mathrm{~cm} \times 50 \mathrm{~cm}$ and cylinders of size $15 \mathrm{~cm}$ diameter $\times 30 \mathrm{~cm}$ height were cast to find out the flexural and split tensile strength respectively for different combinations of GPC. As specified in Indian standard code, fresh and hardened GPC was tested [28, 29]. XRD analysis (ULTIMA-III instrument using $\mathrm{CuK} \alpha$ as a radiation source) was performed on $15 \%$ UFGGBFS based GPC. Fig. 1 shows the mix proportions.

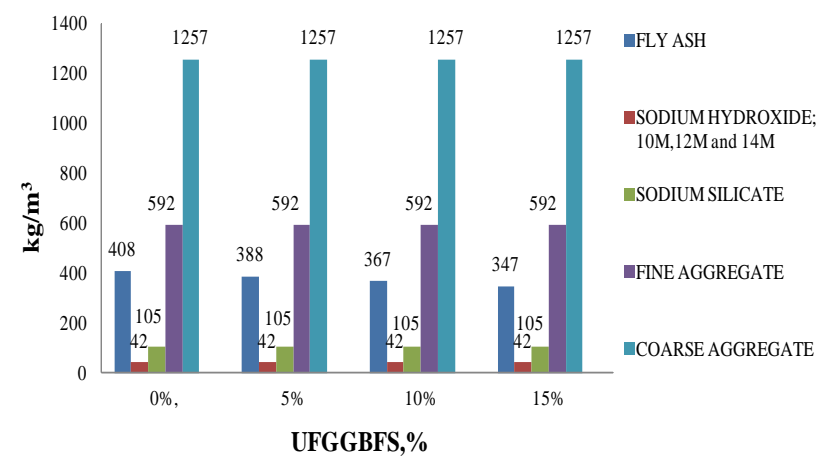

Fig. 1. Mix proportion of copper slag based GPC

Table 1. Chemical and physical properties of fly ash

\begin{tabular}{|l|c|c|c|c|c|c|c|c|}
\hline Sample & $\mathrm{SiO}_{2}$ & $\mathrm{Al}_{2} \mathrm{O}_{3}$ & $\mathrm{Fe}_{2} \mathrm{O}_{3}$ & $\mathrm{Na}_{2} \mathrm{O}$ & $\mathrm{SO}_{3}$ & $\mathrm{CaO}$ & LOI & Specific surface area \\
\hline Class F flyash & $62.30 \%$ & $29.62 \%$ & $4.55 \%$ & $0.22 \%$ & $0.28 \%$ & $1.2 \%$ & $0.55 \%$ & $322.8 \mathrm{~m}^{2} / \mathrm{kg}$ \\
\hline IS Standard requirement & \multicolumn{2}{|l|}{ Minimum $70 \%$} & Maximum 1.5 \% & Maximum 3\% & - & $5 \%$ & $320 \mathrm{~m}^{2} / \mathrm{kg}$ \\
\hline
\end{tabular}

Table 2. Physical properties and chemical composition of UFGGBFS

\begin{tabular}{|l|l|l|l|}
\hline Physical properties & Chemical composition \\
\hline Property & Values & Property & Values \\
\hline Specific surface area & $12000 \mathrm{~cm}^{2} / \mathrm{gm}$ & Silica $\left(\mathrm{SiO}_{2}\right)$ & $35 \%$ \\
\hline Specific gravity & 2.72 & $\mathrm{CaO}$ & $34 \%$ \\
\hline Bulk density $\left(\mathrm{kg} / \mathrm{m}^{3}\right)$ & $600-700$ & Alumina $\left(\mathrm{Al}_{2} \mathrm{O}_{3}\right)$ & $24 \%$ \\
\hline Average particle size & 4 to 6 micron & Ferric oxide $\left(\mathrm{Fe}_{2} \mathrm{O}_{3}\right)$ & $1.7 \%$ \\
\hline
\end{tabular}


Table 3. Physical and chemical properties of copper slag (CPS)

\begin{tabular}{|l|l|}
\hline CPS components & CPS, \% \\
\hline $\mathrm{Fe}_{2} \mathrm{O}_{3}$ & 55.00 \\
\hline $\mathrm{SiO}_{2}$ & 31.20 \\
\hline $\mathrm{Al}_{2} \mathrm{O}_{3}$ & 2.42 \\
\hline $\mathrm{MgO}$ & 1.54 \\
\hline $\mathrm{CaO}$ & 5.37 \\
\hline $\mathrm{Na}_{2} \mathrm{O}$ & 0.25 \\
\hline $\mathrm{SO}_{3}$ & 1.92 \\
\hline $\mathrm{K}_{2} \mathrm{O}$ & 0.66 \\
\hline Specific gravity & 3.50 \\
\hline
\end{tabular}

\section{RESULTS AND DISCUSSION}

\subsection{Effect on workability}

Workability, one of the significant properties of plastic concrete, was done using slump cone apparatus as stated in IS 1199: 1959 Standard [29]. Fig. 2 shows the slump values of GPC (10M, 12M and 14M) with different percentages of UFGGBFS ( 0 \%, 5 \%, $10 \%$ and $15 \%$ ). From Fig. 1, it can be inferred that the rise in molarity results in a decrease of workability. UFGGBFS (0 \%, $5 \%, 10 \%$ and $15 \%$ ) showed an increase in slump value for 10M GPC when compared to $12 \mathrm{M}$ and 14M GPC. Rise in UFGGBFS percentage from $0 \%$ to $15 \%$ within $10 \mathrm{M}, 12 \mathrm{M}$ and $14 \mathrm{M}$ showed increased slump value. For 10M GPC slump value of $120 \mathrm{~mm}$ to $155 \mathrm{~mm}$ was achieved, similarly for $12 \mathrm{M}$ and $14 \mathrm{M}$ slump value was found to be between $110 \mathrm{~mm}$ to $150 \mathrm{~mm}$. The reason for this could be due to the formation of high alkaline content followed by sticky behavior of materials. The reaction of $\mathrm{CaO}$ content along with increased $\mathrm{NaOH}$ concentration reduces the workability of $14 \mathrm{M}$ and $12 \mathrm{M}$ when compared to $10 \mathrm{M}$. The workability was also affected due to the hardening process; this may be due to the presence of calcium content in binding materials like fly ash and UFGGBFS. These materials formed supplementary nucleation spots which increased the solidification rate resulting in an increased rate of hardening process [30, 31]. Also, it was examined whether the increase in the percentage of UFGGBFS elevated the workability of each molarity. Due to water impermeability, the flow ability of GPC improved. The addition of CPS enhanced the workability which may be due to particle size, fineness modulus of CPS and changes in binder content. The existence of UFGGBFS, fly ash and CPS enhance the flow ability of GPC which resulted in better workability.

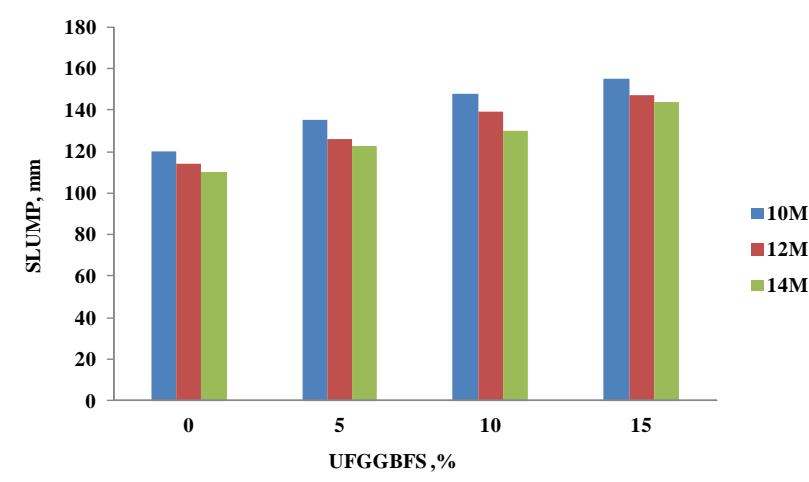

Fig. 2. Workability of copper slag based GPC

\subsection{Effect of split tensile strength}

The split tensile strength result of 7 and 28 days cured specimens are presented in Fig. 3. From Fig. 3, it can be noticed that the rise in molarity of $\mathrm{NaOH}$ results in elevation of strength value. Results revealed an increase of strength in GPC specimens. Average split tensile strength value for $10 \mathrm{M}, 12 \mathrm{M}$ and $14 \mathrm{M}$ GPC at 7 days (curing) was found to be between 2.85 MPa to $3.47 \mathrm{MPa}$ and for 28 days (curing) it was found to be between 2.98 MPa to $4.15 \mathrm{MPa}$. A similar rate of strength increment trend as in compressive strength was observed in split tensile strength. Replacement of UFGGBFS (5 \%, $10 \%$ and $15 \%$ ) showed a rise in splitting tensile strength with the rise in molarity. Rate of strength increase was observed in $12 \mathrm{M}$ and $14 \mathrm{M}$ respectively when compared with 10M. The addition of UFGGBFS increased the polymerization due to the presence of calcium. The reaction of $\mathrm{SiO}_{2}, \mathrm{Al}_{2} \mathrm{O}_{3}$ along with alkaline solution can differ during reaction time. Presence of calcium reacts with the solution (alkaline) and thus development of heat occurs in GPC resulting in strength development. Presence of sodium silicate helps in the bonding of unreacted particles along with the gel matrix and thus improving the mechanical properties [32-34]. Presence of silica and alumina in the mineral admixture combines with alkali gel and thus crosslink gel is formed which acts as a binding material and improves the GPC performance. The presence of calcium oxide improved the cementitious gel and thus improved the binder-aggregate zone. The dissolution of ingredients such as silica and alumina takes place due to the amorphous condition of copper slag along with the alkaline solution. Silico-aluminates structures (3D network) are formed by sodium aluminate silicate hydrate (NASH) and polycondensation which attributes higher GPC strength. Increased $\mathrm{NaOH}$ molarity helps in the formation of NASH. [35]. From this experimental study, it is concluded that split tensile strength increases with the increasing quantity of UFGGBFS, CPS and NaOH molarity.

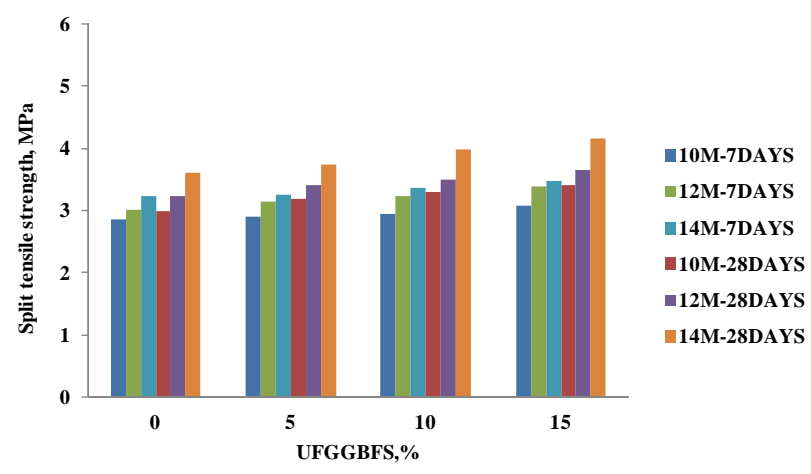

Fig. 3. Split tensile strength of copper slag based GPC

\subsection{Effect of flexural strength}

Average flexural strength test results are depicted in Fig. 4. Flexural strength effect after 7 and 28 days was found to be good with the rise in $\mathrm{NaOH}$ molarity. Similar to split tensile, this test also showed an increase in flexural strength. All the specimens after 7 days curing showed good flexural strength, the values were found between $3.4 \mathrm{MPa}$ to 4.4 MPa. Similarly, the flexural strength after 28 days 
curing was found between 3.6 MPa to 4.8 MPa. Comparison between $10 \mathrm{M}$ and $12 \mathrm{M}, 12 \mathrm{M}$ and $14 \mathrm{M}$ for UFGGBFS $15 \%$ shows an increasing trend of flexural strength. Similar to split tensile strength, 5\%, $10 \%$ UFGGBFS based GPC showed an increase in flexural strength percentage for all molarity when correlated with $100 \%$ fly ash based GPC. When comparing with split tensile strength, flexural strength records a higher percentage of strength increment. The strength improvement was found to better in 14M GPC containing UFGGBFS. The rise in strength is caused by the formation of CSH gel and due to bonding created by adding UFGGBFS [36]. Incorporation of mineral admixtures elevates the $\mathrm{Si} / \mathrm{Al}$ ratio as a result increases the calcium alumino-silicate hydrate (CASH) attributing to good flexural strength.

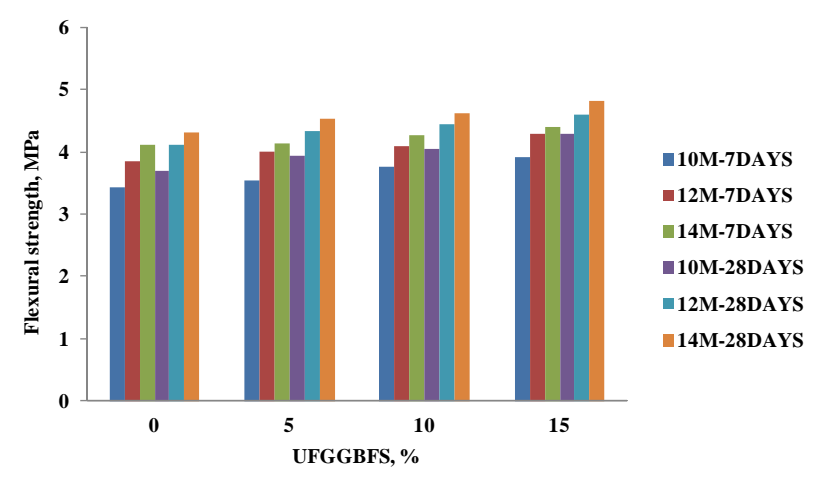

Fig. 4. Flexural strength of copper slag based GPC

\subsection{XRD analysis of GPC}

The crystalline phases of GPC were examined by XRD. The chemical composition of GPC (10M, 12M and 14M) specimen for UFGGBFS (15\%) was examined through $\mathrm{XRD}$ and is shown in Fig. 5.

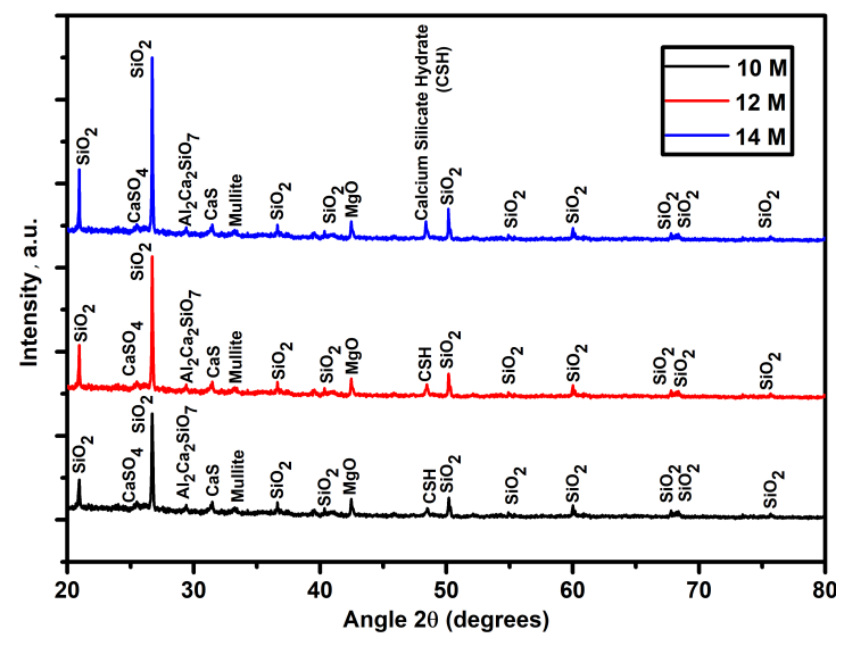

Fig. 5. XRD of $15 \%$ UFGGBFS based GPC

It can be inferred from the XRD pattern that; quartz $\left(\mathrm{SiO}_{2}\right), \mathrm{MgO}$, mullites and calcium silicates $(\mathrm{CaS})$ were dominant at peak crystalline phases. Crystalline phase partial dissolution takes place and as a result of decreased intensity of crystalline humps was observed, mainly due to mineral admixtures. The overall microstructure becomes denser because of the increase in UFGGBFS which indicates the high peak of quartz, which is crystalline in nature. The increased $\mathrm{NaOH}$ molarity results in the high peak of mullite, magnesium oxide and quartz. Copper slag addition indicates amorphous nature and results in the nonidentification of products that were formed in alkali activation [37]. Any change in the hump affects the efficiency of the amorphous gels [38]. Additional CSH gel formation at ambient curing was also found due to the pozzolanic reaction of UFGGBFS which leads to high strength. The mixed nature of amorphous and crystalline morphology is mainly due to ambient curing, a rise in temperature results in change of amorphous nature to crystalline form [39]. Absence of Fe improves the performance of GPC. Geopolymer gel (CASH \& NASH) along with CSH gel densifies the structure of GPC.

\subsection{Microstructure of GPC specimen with $15 \%$ UFGGBFS}

The morphological character and microstructure were studied by SEM. Fig. 6 shows the SEM analysis of $14 \mathrm{M}$ GPC with $15 \%$ UFGGBFS. Hydration of UFGGBFS produces a higher amount of CSH gel, together with a significant bonding of the microstructure. Partial amount of amorphous and cluster network gels were generated; which are clubbed with remaining particles to form denser gel and microstructure. The SEM images of UFGGBFS and CPS based GPC showed better microstructure and lesser pores. An increase in polymerization and denseness leads to micro cracks. The existence of $\mathrm{Na}$ in the gel helps in the formation of NASH. The existence of calcium oxide in UFGGBFS is the main reason for the rate of hydration. Alkali activation results in the heat of hydration, which leads to higher strength and dense microstructure. One of the essential aspects in analyzing the performance of the geopolymer matrix is the $\mathrm{Al} / \mathrm{Si}$ ratio. 14M GPC mix improved interfacial transition zone.

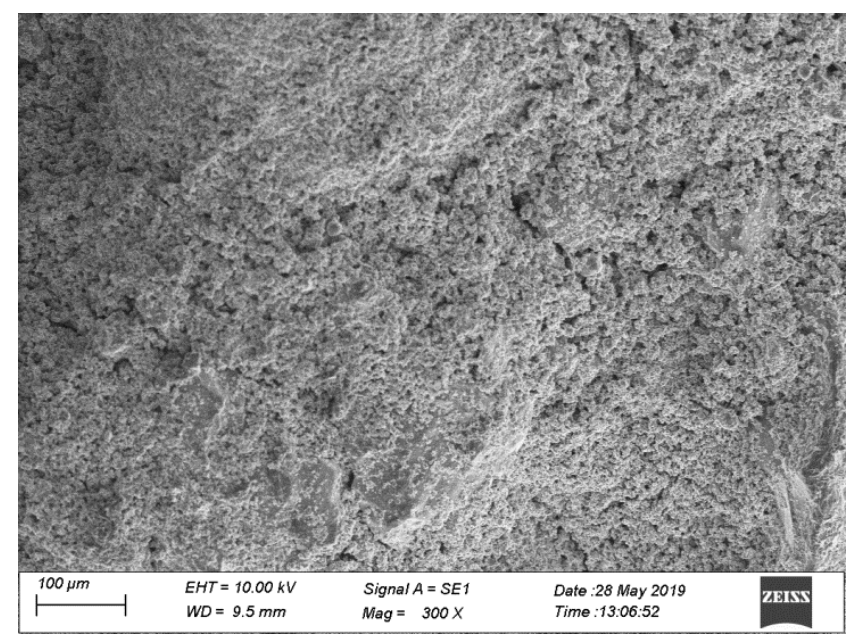

Fig. 6. SEM of $15 \%$ UFGGBFS based GPC

\section{CONCLUSIONS}

Following conclusions are made from this study:

1. The improvement of concrete strength is directly proportional to the molarity ratio and it is also enhanced by the inclusion of UFGGBFS and copper slag in GPC.

2. Addition of slag improves the split tensile and flexural strength properties of GPC. 
3. Strength percentage increases with addition to UFGGBFS and results in denser microstructure concrete which improved the bonding ability.

4. Overall, the performance of GPC increases with the increase in molarity, but the workability reduces.

5. The XRD and SEM results conclude that $\mathrm{CSH}$ and NASH helped in strength development.

6. Varied mix proportion and addition of slag improved the different characteristics of GPC.

7. Copper slag can be used as an alternative fine aggregate.

8. Strength of Ambient cured UFGGBFS based GPC was found to be better than $60^{\circ}$ cured non UFGGBFS based GPC.

9. Using UFGGBFS, CPS and fly ash in GPC prevents environmental pollution, and it can be employed in construction projects.

\section{REFERENCES}

1. Ahmari, S., Ren, X., Toufigh, V., Zhang, L. Production of Geopolymeric Binder from Blended Waste Concrete Powder and Fly Ash Construction and Building Materials 35 2012: pp. $718-729$.

https://doi.org/10.1016/j.conbuildmat.2012.04.044

2. Gartner, E. Industrially Interesting Approaches To "Low$\mathrm{CO}_{2}$ ” Cement Cement and Concrete Research 34 (9) 2004: pp. 1489-1498.

https://doi.org/10.1016/j.cemconres.2004.01.021

3. Davidovits, J. Global Warming Impact on the Cement and Aggregates Industries World Resource Review 6(2) 1994: pp. 263-278.

4. Aïtcin, P.C. Cements of Yesterday and Today: Concrete of Tomorrow Cement and Concrete Research 30 2000: pp. $1349-1359$.

https://doi.org/10.1016/S0008-8846(00)00365-3

5. Radlinski, M., Harris, N.J., Moncarz, P. Sustainable Concrete: Impacts of Existing and Emerging Materials and Technologies on the Construction Industry Architectural Engineering Conference 2011: pp. 252-262.

https://doi.org/10.1061/41168(399)31

6. Worrell, E., $\quad$ Price, L., $\quad$ Martin, N., Hendriks, C., Meida, L.O. Carbon Dioxide Emissions from the Global Cement Industry Annual Review of Energy and the Environment 26 2001: pp. 303-329. https://doi.org/10.1146/annurev.energy.26.1.303

7. Schneider, M., Romer, M., Tschudin, M., Bolio, $\mathbf{H}$. Sustainable Cement Production Present and Future Cement and Concrete Research 41 (7) 2011: pp. 642-650. https://doi.org/10.1016/j.cemconres.2011.03.019

8. Jindal, B.B. Feasibility Study of Ambient Cured Geopolymer Concrete - A Review Advances in Concrete Construction 6 (4) 2018: pp. 387-405.

https://doi.org/10.12989/ACC.2018.6.4.387

9. Jindal, B.B., Singhal, D., Sharma, S.K., Parveen, J. Enhancing Mechanical and Durability Properties of Geopolymer Concrete With Mineral Admixture Computer Concrete 21 (3)L 2018: pp. 345-353.

10. Anbarasan, I., Soundarapandian, N. Investigation of Mechanical And Micro Structural Properties of Geopolymer Concrete Blended by Dredged Marine Sand and Manufactured Sand Under Ambient Curing Conditions Structural Concrete 2019: pp. 1-12.

https://doi.org/10.1002/suco.201900343
11. Meesala, C.R., Verma, N.K., Kumar, S. Critical Review on Fly-Ash Based Geopolymer Concrete Structural Concrete 2019: pp. $1-16$. https://doi.org/10.1002/suco.201900326

12. Noushini, A., Aslani, F., Castel, A., Gilbert, R.I., Uy, B., Foster, S. Compressive Stress Strain Model for LowCalcium Fly Ash-Based Geopolymer and Heat-Cured Portland Cement Concrete Cement and Concrete Composites 2016: pp. $136-146$. https://doi.org/10.1016/j.cemconcomp.2016.07.004

13. Anuradha, R., Sreevidya, V., Venkatasubramani, R., Rangan, B.V. Modified Guidelines for Geopolymer Concrete Mix Design Using Indian Standard Asian Journal of Civil Engineering (Building and Housing) 13 (3) 2012: pp. 353-364.

14. Nath, P., Sarker, P.K. Use of OPC to Improve Setting and Early Strength Properties of Low Calcium Fly Ash Geopolymer Concrete Cured at Room Temperature Cement and Concrete Composites 55 2015: pp. 205-214. https://doi.org/10.1016/j.cemconcomp.2014.08.008

15. Lateef, H., Azreen, M., Ari, M., Noori, M., Warid, M. Self-compacting Geopolymer Concrete With Spend Garnet as Sand Replacement Journal of Building Engineering 15 2017: pp. 85-94. https://doi.org/10.1016/j.jobe.2017.10.007

16. Gorai, B., Jana, R.K., Premchand. Characteristics and Utilization of Copper Slag - A Review Conservation and Recycling 39 (4) 2003: pp. 299-313. https://doi.org/10.1016/S0921-3449(02)00171-4

17. Kambham, K., Sangameswaran, S., Datar, S.R., Kura, B. Copper slag: Optimization of Productivity and Consumption for Cleaner Production in Dry Abrasive Blasting Journal of Cleaner Production 15 2007: pp. 465-473. https://doi.org/10.1016/j.jclepro.2005.11.024

18. Mahendran, K., Arunachelam, N. Study on Utilization of Copper Slag As Fine Aggregate in Geopolymer Concrete International Journal of Applied Engineering Research 10 2015: pp. 336-340.

19. Mahendran, K., Arunachelam, N. Performance of Fly Ash and Copper Slag based Geopolymer Concrete Indian Journal of Science and Technology 9 2016: pp. 0974-5645. https://doi.org/10.17485/ijst/2016/v9i2/86359

20. Junaid, M.T., Khennane, A., Kayali, O., Sadaoui, A., Picard, D., Fafard, M. Aspects of the Deformational Behaviour of Alkali Activated Fly Ash Concrete at Elevated Temperatures Cement and Concrete Research 60 2014: pp. 24-29. https://doi.org/10.1016/j.cemconres.2014.01.026

21. Chithambaram, S.J., Kumar, S., Prasad, M.M., Adak, D. Effect of Parameters on the Compressive Strength of Fly Ash Based Geopolymer Concrete Structural Concrete 2018: pp. $1-8$. https://doi.org/10.1002/suco.201700235

22. Mithun, B.M., Narasinhan, M.C. Performance of Alkali Activated Slag Concrete Mixes Incorporating Copper Slag As Fine Aggregate Journal of Cleaner Production 112 (1) 2016: pp. $837-844$. https://doi.org/10.1016/j.jclepro.2015.06.026

23. IS 3812:2003. Indian Standard Pulverized Fuel Ash Specification. Bureau of Indian Standards. New Delhi, India, 2003.

24. Jindal, B.B., $\quad$ Yadav, A., $\quad$ Anand, A., $\quad$ Badal, A. Development of High Strength Fly Ash Based Geopolymer 
Concrete With Alccofine IOSR Journal of Mechanical and Civil Engineering 2016: pp. 55-58. https://doi.org/10.9790/1684-15010010155-58

25. IS 383:2006. Indian Standard Specification for Coarse and Fine Aggregates from Natural Sources for Concrete Bureau of Indian Standards. New Delhi, India, 2006.

26. IS 2386:1963. Indian Standard Methods of Test For aggregates Concrete - Part I Particle Size and Shape. Bureau of Indian Standards. New Delhi, India, 1963.

27. IS 9103:1999. Indian Standard Concrete Admixtures Specification. Bureau of Indian Standards. New Delhi, India, 1999.

28. IS 516:1959. Indian Standard Methods of Tests for Strength of Concrete. Bureau of Indian Standards. New Delhi, India, 1959.

29. IS 5816:1999. Indian Standard Splitting Tensile Strength of Concrete - Method of Test. Bureau of Indian Standards. New Delhi, India, 1999.

30. Vijayasarathy, R., Jayabalan, P., Karthikeyan, J. Effect of Ultrafine Ground Granulated Blast-Furnace Slag (UFGGBFS) and Copper Slag on Ambient Cured Geopolymer Concrete Annales de Chimie - Science des Matériaux 43 (6) 2019: pp. 377-382.

31. Parveen, J., Singhal, D., Junaid, M.T., Jindal, B.B., Mehta, A. Mechanical and Microstructural Properties of Fly Ash Based Geopolymer Concrete Incorporating Alccofine At Ambient Curing Construction and Building Materials 180 2018: pp. 298-307. https://doi.org/10.1016/j.conbuildmat.2018.05.286

32. Jindal, B.B., Singhal, D., Sharma, S.K., $\quad$ Ashish, D.K., Parveen, J. Improving Compressive Strength of Low Calcium Fly Ash Geopolymer Concrete With Alccofine Advances in Concrete Construction 5 (1) 2017: pp. 17-29. https://doi.org/10.12989/acc.2017.5.1.17

33. Fernández-Jiménez, A., Puertas, F., Sobrados, I., Sanz, J. Structure of Calcium Silicate Hydrates Formed in AlkalineActivated Slag: Influence of The Type of Alkaline Activator Journal of the American Ceramic Society 86 (8) 2003: pp. 1389-1394. https://doi.org/10.1111/j.1151-2916.2003.tb03481.x

34. Allahverdi, A., Kani, E.N. Use of Construction and Demolition Waste (CDW) for Alkali-Activated or
Geopolymer Cements, in: Pacheco-Torgal F, Tam V, Labrincha J, Ding Y, de Brito J (Eds.). Handbook of Recycled Concrete and Demolition Waste, Woodhead Publishing, Cambridge. 2013: pp. 439-475.

https://doi.org/10.1533/9780857096906.3.439

35. Saha, S., Rajasekaran, C. Enhancement of The Properties Of Fly Ash Based Geopolymer Paste By Incorporating Ground Granulated Blast Furnace Slag Construction and Building Materials 146 2017: pp. 615-620. https://doi.org/10.1016/j.conbuildmat.2017.04.139

36. Jindal, B.B., $\quad$ Singhal, D., Sharma, S., $\quad$ Yadav, A., Shekhar, S., Anand, A. Strength and Permeation Properties of Alccofine Activated Low Calcium Fly Ash Geopolymer Concrete Computers and Concrete 20 (6) 2017: pp. 683-688.

37. Singh, J., Singh, S.P. Development of Alkali-activated Cementitious Material using Copper Slag Construction and Building Materials 211 2019: pp. 73-79. https://doi.org/10.1016/j.conbuildmat.2019.03.233

38. Ibrahim, M., Johari, M.A.M., $\quad$ Rahman, M.K., Maslehuddin, M. Effect of Alkaline Activators and Binder Content on The Properties of Natural Pozzolan-Based Alkali Activated Concrete Construction and Building Materials 147 2017: pp. 648-660. https://doi.org/10.1016/j.conbuildmat.2017.04.163

39. Okoye, F.N., Durgaprasad, J., Singh, N.B. Mechanical Properties of Alkali Activated Flyash/Kaolin Based Geopolymer Concrete Construction and Building Materials 98 2015: pp. 685-691. https://doi.org/10.1016/j.conbuildmat.2015.08.009

40. Singh, B., Rahman, M.R., Paswan, R., Bhattacharyya, S K. Effect of Activator Concentration on the Strength, ITZ and Drying Shrinkage of Fly Ash/Slag Geopolymer Concrete Construction and Building Materials 118 2016: pp. $171-179$. https://doi.org/10.1016/j.conbuildmat.2016.05.008

41. Chitrala, S., Jawahar, J., Sashidhar, C. Effect of Copper Slag on Micro, Macro, and Flexural Characteristics of Geopolymer Concrete Journal of Materials in Civil Engineering 32 2020: pp. 1-12. https://doi.org/10.1061/(ASCE)MT.1943-5533.0003157

(c) Rathanasalam et al. 2021 Open Access This article is distributed under the terms of the Creative Commons Attribution 4.0 International License (http://creativecommons.org/licenses/by/4.0/), which permits unrestricted use, distribution, and reproduction in any medium, provided you give appropriate credit to the original author(s) and the source, provide a link to the Creative Commons license, and indicate if changes were made. 